\title{
Study on the Multivariant Interactive Teaching Modes of College English under the Information Technology Environment
}

\author{
Fangfang Chen \\ School of Foreign Languages, Jinzhong University, China \\ E-mail: fangfang_chen@163.com
}

Keywords: Information technology environment, multivariant interactive, college english, teaching mode

Received: July 15, 2019

\begin{abstract}
Teaching modes can achieve twice the result with half the effort for teaching effect. The multivariant interactive teaching modes based on constructivism theory are a new kind of teaching modes supported by information technology. The multivariant interactive College English teaching modes under the information technology environment has changed the relationship between teachers and students in the classroom teaching process and the relationship between teachers and students and the teaching content. It can improve the quality of English teaching to achieve the goal of effectively improving the teaching effect of the course and improving students' ability of using English language. Based on the background of the information technology environment, this research takes the college students as the object and the multivariant interactive teaching modes as the research method and analyzes the effectiveness of the multivariant interactive teaching modes through an example.
\end{abstract}

Povzetek: Opisana in testirana je multivariantna analiza učenja angleščine.

\section{Introduction}

The rapid development of information technology is gradually changing the traditional teaching environment and means. Foreign language educators should make full use of advanced digital technology to absorb and inherit the original teaching advantages to the maximum, making it easier for College English teaching to turn from the teacher centered to the "multivariant interactive" teaching mode between students and computers, students and students, students and teachers. Information-based "multivariant interactive" teaching is the development direction of College English teaching. Therefore, one of the main objectives of the reform of the current teaching mode is to construct a new teaching structure which can not only play the guiding role of teaching but also fully reflect the main role of the students. The multivariant interactive teaching modes under the digital technology environment have strong interactivity. It can realize interaction between students and computers, interaction between students and students, interaction between students and teachers, and interaction between students and learning content. The direction of interaction can also be one to one, one to many, or multivariant to many "multivariant interactive" [1].

\section{Related research based on the multivariant interactive teaching modes}

\subsection{The connotation of multivariant interactive teaching modes}

"Multivariate" is the meaning of multivariant elements and multivariant essential factors. "Multivariant interactive" is the process of interaction and interlinking of multivariant elements. In the course of teaching, "multivariate" refers to the teaching elements related to teaching activities, such as teachers' elements, students' elements, teaching environment elements, material conditions elements, and textbook elements and so on. Therefore, "multivariant interactive" can be defined as a process in which various elements related to teaching activities interact and influence each other. The multivariant interactive in the course of teaching is a series of teaching and learning activities, which can make use of the factors of teachers, students and teaching environment to improve the students' interest in learning actively, improve the students' learning state and effect, and achieve a high quality and efficient teaching effect [2].

\subsection{The characteristics of multivariant teaching modes}

(1) Integrating multivariant teaching methods. The multivariant interactive teaching modes intertwined the teaching method, teaching means, teaching content and teaching organization form into an interactive one. It changes the relatively abstract education idea into a 
specific operational strategy, and encourages students to feel, judge and practice and adjust their learning behaviors in an all-round way [3].

(2) An open teaching environment. The multivariant interactive teaching modes are open, and the classroom under this mode is an activity class. Before and after class, students must read a lot and grasp certain vocabularies so that they can interact effectively in class. The information technology environment also increases the interaction between students and teachers, so that students can interact with others in the virtual social situation, which helps students to play the role of emotional factors in language learning [4].

(3) An equal relationship between teachers and students. The multivariant interactive teaching mode advocates the establishment of an equal interaction between teachers and students. It respects the students' personality and experience, encourages and trains the students' spirit of independent exploration, interaction and practice and innovation, and tries to create a relaxed and harmonious interactive teaching situation. Students choose different learning methods according to their special situations and learning requirements, and actively participate in the whole interactive teaching process.

(4) A variety of teaching forms. The multivariant interactive teaching modes are opposed to the stereotyped and traditional instilled teaching, which focuses on that students actively and collaboratively acquire knowledge.

\section{Experimental designs of multivariant interactive teaching modes of college English under information technology environment}

The experimental subjects were a comprehensive university, which includes both freshmen who have just entered the university and seniors of the sophomore year. Freshmen organize classes in administrative classes, and old students independently choose courses according to the credit system management system, so students in a class may come from different professional classes. There are mainly four teachers involved in experimental teaching work, all of whom are members of the research group of this project. They have not only division of labor, but also cooperation, and are involved in listening and speaking experimental teaching [5]. This chapter intends to elaborate on the design of listening and speaking experiment teaching and the survey of teachers' teaching beliefs.

(1) The research problem of the experiment

1) Whether the multivariant interactive teaching modes can play a positive role in the cultivation of students' awareness of oral communication strategic and the using frequency of communicative strategy;

2) Whether the multivariant interactive teaching modes can promote the formation of students' independent learning ability and cooperative ability;
3) Whether the multivariant interactive teaching modes can provide students with meaningful input and output environment.

(2) Experimental object

The object of this study is the first-grade students of grade 16 law school in our university. They are students of two natural classes whose majors are law. Before the experiment, we calculate the average score for statistics after converting subjects learning background and English college entrance examination results into percentile, and the results are shown as shown in Table 1. The two classes who participated in the experiment used the same listening and speaking teaching materials and the independent learning network platform, that is, the "Experiencing English College English learning system", which is newly developed in the first volume of College English listening and speaking course [6]. The system is installed on the server based on campus network, and students can log in and study at any time. From table 1 and Figure 1, it can be seen that the English foundation of the subjects is basically the same. The time distribution of their extracurricular English learning every week in middle school is basically the same. The 1 class was taken as the experimental class and the 2 class was taken as the control class.

\begin{tabular}{|c|c|c|}
\hline & $\begin{array}{c}1 \text { class } \\
\text { (Experimental class) }\end{array}$ & $\begin{array}{c}2 \text { class } \\
\text { (control class) }\end{array}$ \\
\hline The number of students & 38 & 36 \\
\hline The number of girls & 20 & 19 \\
\hline Entrance average achievement & 78.21 & 79.79 \\
\hline The number of people fromkey middle schools & 33 & 36 \\
\hline Extracumicular listening time every week (hours) & 1.2 & 1.4 \\
\hline Extracuricular oral language time every week (hours) & 1.1 & 1.2 \\
\hline Extracuricular reading time every week (hour) & 3.3 & 3 \\
\hline Extracuricular writing time every week (hours) & 2.1 & 1.9 \\
\hline Extracuricular translation time every week(hours) & 0.5 & 0.5 \\
\hline
\end{tabular}

Table 1: Learning background and College Entrance Examination Statistics

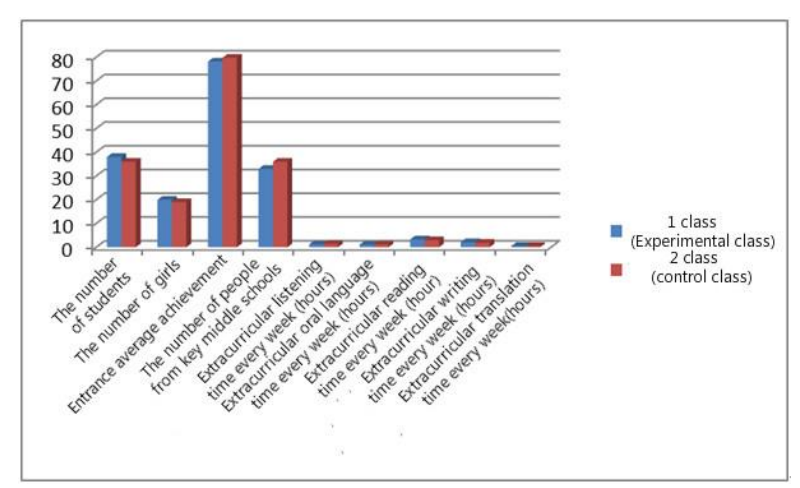

Figure 1: The comparison situation of the subjects being studied.

(3) Experimental scheme

The experimental scheme is:

1) Selecting the subjects, they were divided into experimental class and control class, and their oral learning strategies, communication strategies and metacognitive strategies were investigated.

2) Assigning tasks and goals of "teachers and students, students and students, students and machine" interactive teaching for students in experimental class and developing an autonomous learning plan. 
3) After the end of the experiment, the change situation of the oral learning strategies and the use of communication strategies in the experimental class and the control class were investigated through questionnaires.

4) Listening and speaking tests were conducted in both the experimental class and the control class and comparing the differences between their achievements.

5) Through the learner's autonomous learning program, the feedback table is executed, and the students' subjective evaluation of "teachers and students, students and students, students and machine" interactive teaching is understood through the students' learning diary and the students' interview.

6) The differences between autonomous learning ability and cooperative ability of the experimental class and the control class were compared.

(4) Experimental tool

There are three kinds of research tools used in the experiment. The first is the questionnaire, including the English learning strategy questionnaire and the cooperative feeling questionnaire. The second is audiovisual test. The third is the students' own subjective evaluation, including study diary or weekly diary and interview, and the implementation feedback form of learner's independent learning plan [7]. This research uses SPSS13.0 statistics to process data.

\section{Analysis of the Experimental Results of Multivariant Interactive Teaching in College English under Information Technology Environment}

\subsection{The experimental process of listening and speaking experimental teaching}

Listening and speaking experimental teaching started from the end of September 2016 and ended at the end of January 2017, which lasted for 12 weeks. During the first week of freshmen, the using frequency of English learning strategies, audio-visual tests and oral English learning needs analysis were conducted in the experimental class and the control class. Then the teaching plan was introduced to the experimental class, emphasizing the importance of cooperative learning and autonomous learning. In addition, an experimental class was trained in oral learning strategy, oral communication strategy and independent learning, and the content and operation of oral communication strategy and metacognitive strategy were introduced gradually. From the beginning of the second week, combined with the teaching resources (the new edition of "College English audio-visual Speaking Course 1"), the "College English learning system" has carried out the teaching practice based on autonomous learning and cooperative learning in the experimental class, which requires the students to complete each specific learning task seriously. The control class also emphasizes the significance of cooperative ability and autonomous learning, and encourages students to develop autonomous learning, but it does not activate oral communication strategies and strategy training. When completing each specific learning task, we advocate cooperative learning and independent learning. In January 2017, the applied situation of oral communication strategies of two classes was surveyed again. Finally, two classes took part in the audio-visual speaking ability test [8].

\subsection{Example description}

College English listening and speaking "teachers and students, students and students, students and machine" interaction based on autonomous learning and cooperative learning is shown in Figure 2. The solid line is strong and the dotted line is weak.

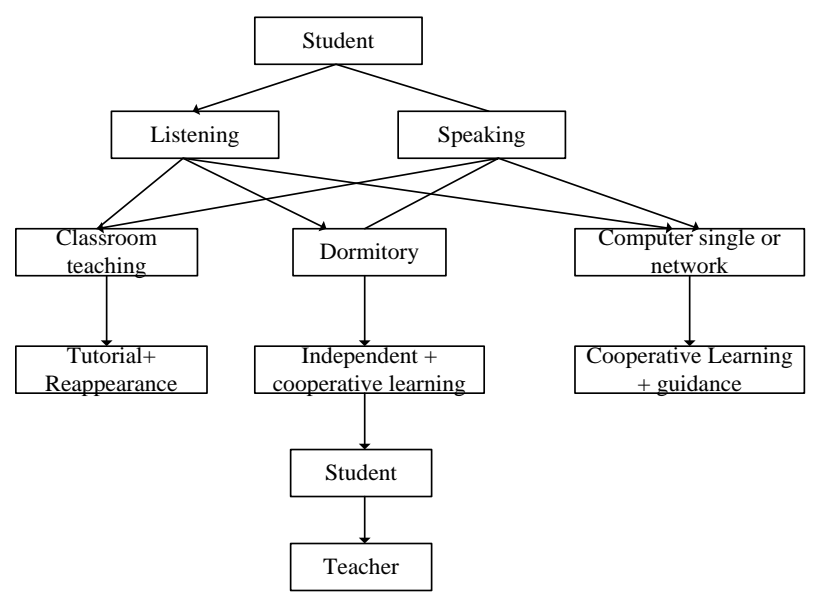

Figure 2: "Teachers and students, students and students, students and machine" interaction.

\subsection{Experimental results and analysis}

(1) Survey results of the use of oral strategy

Before and after the experiment, we made statistics and analysis on the pretest and posttest of the two oral tests in the control class and the experimental class, and the survey situation of oral communication strategy using. The results are shown in Table 2 and Figure 3.

\begin{tabular}{|c|c|c|c|c|c|c|}
\hline & & Mean value & Variance & Free of degree & t value & Probability \\
\hline Pretest & Control class & 0.63 & 0.45 & 74 & 1.237 & 0.22 \\
\cline { 2 - 5 } & Experimental class & 0.49 & 0.53 & & & \\
\hline \multirow{2}{*}{ Posttest } & Control class & 1.05 & 0.31 & 74 & 1.859 & 0.067 \\
\cline { 2 - 7 } & Experimental class & 0.9 & 0.38 & & & \\
\hline
\end{tabular}

Table 2: Horizontal statistics of the strategy using in the control class and the experimental class. 


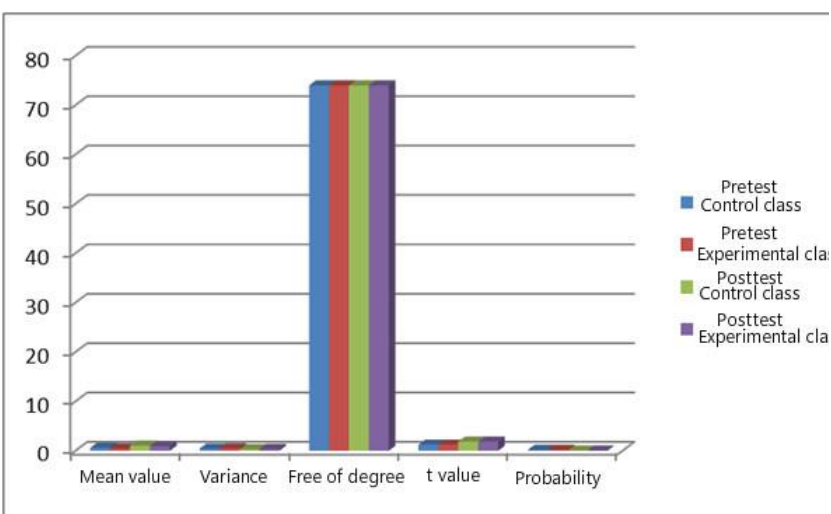

Figure 3: Lateral contrast diagram.

\begin{tabular}{|c|c|c|c|c|c|c|}
\hline & & Mean value & Vaniance & Free of degree & t value & Probability \\
\hline \multirow{2}{*}{ Conirol class } & Pretest & 0.63 & 0.45 & 36 & -4.947 & 0 \\
\cline { 2 - 4 } & Posttest & 1.05 & 0.31 & & & \\
\hline \multirow{2}{*}{ Experimental class } & Pretest & 0.49 & 0.53 & 38 & -3.782 & 0.001 \\
\cline { 2 - 4 } & Posttest & 0.9 & 0.38 & & & \\
\hline
\end{tabular}

Table 3: Longitudinal statistical table of the strategy using in the control class and the experimental class.

As can be seen from table 2 and figure 3, the mean values of the strategy using of the control class and the experimental class 12 weeks ago were 0.63 and 0.49 respectively, and the probability was 0.22 , greater than 0.01 after the p-value test. This shows that the frequency of strategies using of the two classes is relatively low, and the use of oral strategies is almost no difference, and there is little correlation between the strategies using. After 12 weeks of training, the mean value of the strategies using of the control class and the experimental work was improved, while the average price of the control class was slightly higher than that of the experimental class. The probability was 0.067 , more than 0.05 , and less than 0.1 by the p-value test. It shows that the strategies using situation in the two classes has improved, which is gradually different, but the significance is not strong [9].

As can be seen from table 3, the frequency of using strategy is low in the control class and experimental work before 12 weeks. After 12 weeks of training, the frequency of using strategies increased. The probability of using the strategy before and after the experiment in the control class and the experimental class was 0 and 0.001 respectively, all lower than 0.05 by the p-value test. It shows that there are differences before and after the experiment, reaching statistical significance. The probability of irrelevance before and after experiment is almost zero.

(2) Results of listening and speaking tests

In the listening and speaking tests conducted 12 weeks ago and 12 weeks later, the results of the control class and the experimental class were shown in table 4 and table 5 respectively.

From the results of statistics of listening and speaking scores in Figure 4, table 4, table 5, the mean value of listening and speaking scores in pretest of the control class and the experimental class were 16.3, 25.03 and 14.74, 25.72 respectively. After $\mathrm{p}$ value test, the $\mathrm{p}$ value is 0.065

\begin{tabular}{|c|c|c|c|c|c|c|c|}
\hline & & & $\begin{array}{l}\text { Mean } \\
\text { value }\end{array}$ & Variance & $\begin{array}{l}\text { Free of } \\
\text { degree }\end{array}$ & $\mathrm{t}$ value & Probability \\
\hline \multirow[t]{4}{*}{ Pretest } & \multirow[t]{2}{*}{ Listening } & Control class & 16.3 & 3.45 & \multirow[t]{2}{*}{36} & \multirow[t]{2}{*}{1.873} & \multirow[t]{2}{*}{0.065} \\
\hline & & Experimental class & 14.74 & 3.76 & & & \\
\hline & \multirow[t]{2}{*}{ Speaking } & Control class & 25.03 & 1.64 & \multirow[t]{2}{*}{36} & \multirow[t]{2}{*}{-1.958} & \multirow[t]{2}{*}{0.054} \\
\hline & & Experimental class & 25.72 & 1.43 & & & \\
\hline \multirow[t]{4}{*}{ Posttest } & \multirow[t]{2}{*}{ Listening } & Control class & 21.22 & 3.38 & \multirow[t]{2}{*}{38} & \multirow[t]{2}{*}{2.724} & \multirow[t]{2}{*}{0.008} \\
\hline & & Experimental class & 18.9 & 2.99 & & & \\
\hline & \multirow[t]{2}{*}{ Speaking } & Control class & 26.43 & 1.17 & \multirow[t]{2}{*}{38} & \multirow[t]{2}{*}{-2.201} & \multirow[t]{2}{*}{0.031} \\
\hline & & Experimental class & 27.03 & 1.18 & & & \\
\hline
\end{tabular}

Table 4: Horizontal statistics of listening and speaking scores in control class and experimental class.

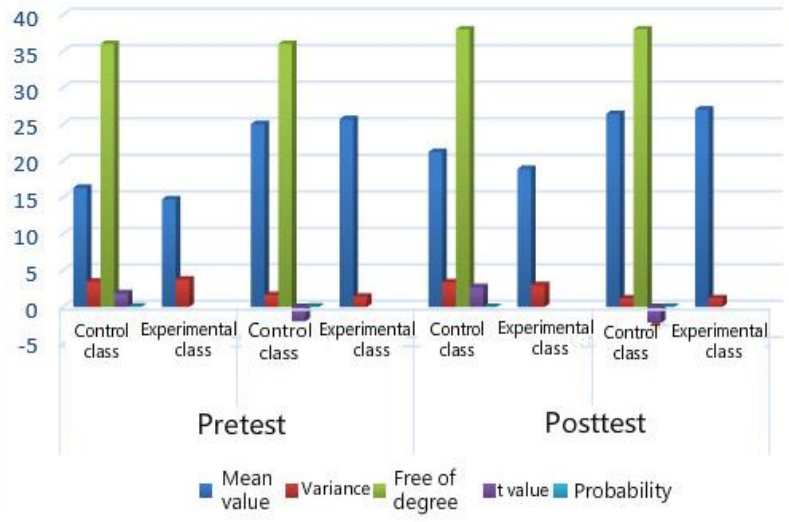

Figure 4: The result statistics of lateral contrast.

\begin{tabular}{|c|c|c|c|c|c|c|c|}
\hline & & & $\begin{array}{l}\text { Mean } \\
\text { value }\end{array}$ & Variance & $\begin{array}{l}\text { Free of } \\
\text { degree }\end{array}$ & $\mathrm{t}$ value & Probability \\
\hline \multirow[t]{4}{*}{ Pretest } & \multirow[t]{2}{*}{ Listening } & Control class & 16.3 & 3.45 & \multirow[t]{2}{*}{36} & \multirow[t]{2}{*}{1.873} & \multirow[t]{2}{*}{0.065} \\
\hline & & Experimental class & 14.74 & 3.76 & & & \\
\hline & \multirow[t]{2}{*}{ Speaking } & Control class & 25.03 & 1.64 & \multirow[t]{2}{*}{36} & \multirow[t]{2}{*}{-1.958} & \multirow[t]{2}{*}{0.054} \\
\hline & & Experimental class & 25.72 & 1.43 & & & \\
\hline \multirow[t]{4}{*}{ Posttest } & \multirow[t]{2}{*}{ Listening } & Control class & 21.22 & 3.38 & \multirow[t]{2}{*}{38} & \multirow[t]{2}{*}{2.724} & \multirow[t]{2}{*}{0.008} \\
\hline & & Experimental class & 18.9 & 2.99 & & & \\
\hline & \multirow[t]{2}{*}{ Speaking } & Control class & 26.43 & 1.17 & \multirow[t]{2}{*}{38} & \multirow[t]{2}{*}{-2.201} & \multirow[t]{2}{*}{0.031} \\
\hline & & Experimental class & 27.03 & 1.18 & & & \\
\hline
\end{tabular}

Table 5: Longitudinal statistics of listening and speaking scores in control class and experimental class.

\begin{tabular}{|c|c|c|c|c|c|c|c|}
\hline & & & $\begin{array}{l}\text { Mean } \\
\text { value }\end{array}$ & Variance & $\begin{array}{l}\begin{array}{c}\text { Free of } \\
\text { degree }\end{array} \\
\end{array}$ & t value & Probability \\
\hline \multirow[t]{4}{*}{ Control class } & \multirow[t]{2}{*}{ Listening } & Pretest & 16.3 & 3.45 & \multirow[t]{2}{*}{74} & \multirow[t]{2}{*}{-10.055} & \multirow[t]{2}{*}{0} \\
\hline & & Posttest & 21.22 & 3.38 & & & \\
\hline & \multirow[t]{2}{*}{ Speaking } & Pretest & 25.03 & 1.64 & \multirow[t]{2}{*}{74} & \multirow[t]{2}{*}{-7.653} & \multirow[t]{2}{*}{0} \\
\hline & & Posttest & 26.43 & 1.17 & & & \\
\hline \multirow{4}{*}{$\begin{array}{l}\text { Experimental } \\
\text { class }\end{array}$} & \multirow[t]{2}{*}{ Listening } & Pretest & 14.74 & 3.76 & \multirow[t]{2}{*}{74} & \multirow[t]{2}{*}{-7.201} & \multirow[t]{2}{*}{0} \\
\hline & & Posttest & 18.9 & 2.99 & & & \\
\hline & \multirow[t]{2}{*}{ Speaking } & Pretest & 25.72 & 1.43 & \multirow[t]{2}{*}{74} & \multirow[t]{2}{*}{-7.563} & \multirow[t]{2}{*}{0} \\
\hline & & Posttest & 27.02 & 1.18 & & & \\
\hline
\end{tabular}

and 0.054 , which are between 0.05 and 0.1 . It shows that the achievement difference between the two classes is not very significant. After 12 weeks, the mean value of listening and speaking scores in the control class and the experimental class were 21.22, 26.43 and 18.9, 27.03 respectively. The value of $p$ is less than 0.05 by the $p$ value test. This indicates that the listening and speaking effects of the two classes are significantly different, and the listening and speaking effects of the experimental class are more significant [10].

\section{(3) Subjective evaluation of students}

The significance of changing the attitude of autonomous learning lies in accepting the mode of autonomous learning and consciously entering the state of autonomous learning. It is difficult to achieve the expected learning effect if the change of independent learning 
attitude only stays in spoken or perfunctory teachers' task requirements. A student from the control class wrote an evaluation of the self-reading task: "medium! The sound quality or the pronunciation of some words is not very good. (Student 1) for the evaluation of the same task, one student from the experimental class wrote, "read the text aloud and read the courseware, so that it is beneficial to the pure pronunciation, correct errors, cultivate the sense of language, and cultivate the ability of self-study." (Student 2) comparing the activities evaluation of two students, we found that the former student was very general. Perhaps he did not know how to improve the level of reading and lacked motivation to insist on reading aloud. Comparatively speaking, the latter student has a deep understanding of reading aloud. In short, the language accumulated through listening and reading can become students' Internalization knowledge and can also become a bridge for them to understand target language. As students become able to learn and learn in the language environment, their chances of leaving teachers for autonomous learning will increase.

\section{Conclusion}

Today, with the rapid development of science and technology and the acceleration of global integration, the demand of society for human resource literacy has changed accordingly. It is a new requirement for the quality of talent in the age of information technology to master and use foreign languages, especially English, to communicate and communicate and to master and use information technology to obtain; process and deal with information. The traditional teaching mode of College English with the goal of acquiring language skills has not been able to meet the needs of the ability of foreign language talents to use foreign languages comprehensively in the development of the times. With students as the center, task as the link and information technology as the means, the goal is to cultivate communicative competence, collaboration ability and improve language skills. The original intention of this research is to build a multi interactive College English teaching mode under the information technology environment and to combine the classroom teaching with autonomous learning. This research takes a university as the research object, and makes an example proving of English listening and speaking. The experimental results show that under the background of information technology, multivariant interactive teaching is conducive to College students' learning and application.

\section{Acknowledgement}

Text of the acknowledgement. This research work is fully supported by School of Foreign Languages in Jinzhong University.

\section{References}

[1] Huffman M K, Schuhmann K, Keller K, et al. Interaction of drift and distinctiveness in L1 English-
L2 Japanese learners[J]. Journal of the Acoustical Society of America, 141(5), pp.3517-3517, 2017. https://doi.org/10.1121/1.4987389

[2] Kim S, Jang J, Cho T. Articulatory characteristics of preboundary lengthening in interaction with prominence on tri-syllabic words in American English[J]. Journal of the Acoustical Society of America, 142(4), pp.362, 2017. https://doi.org/10.1121/1.5005132

[3] [3] Huiyong Yang. Comprehensive Evaluation of College English Teaching Mode Based on Online Courses: An Educational Practice from Anhui Polytechnic University[J]. International Journal of Future Generation Communication and Networking, vol. 9, no. 2, pp. 219-230, 2016. https://doi.org/10.14257/ijfgcn.2016.9.2.23

[4] [4] Triantafyllidis A K, Koutkias V G, Chouvarda I, et al. Framework of sensor-based monitoring for pervasive patient care $[\mathrm{J}]$. Healthcare Technology Letters, 3(3), pp.153-158, 2017. https://doi.org/10.1049/htl.2016.0017

[5] [5] Lee Jung Jae; Carson Maggie N; Clarke Charlotte L; Yang Sook Ching; Nam Su Jin.Nursing students' learning dynamics with clinical information and communication technology: A constructive grounded theory approach.[J]Nurse education today.pp.41-47.2018 https://doi.org/10.1016/j.nedt.2018.11.007

[6] [6 ]Fuentes C D, Dutrénit G. Geographic proximity and university-industry interaction: the case of Mexico[J]. Journal of Technology Transfer, 41(2), pp.329-348, 2016. https://doi.org/10.1007/s10961-014-9364-9

[7] [7] Neto P, Moreira A P. Preface for the special issue on robotics in smart manufacturing[J]. International Journal of Advanced Manufacturing Technology, 85(1-4), pp.1-1, 2016. https://doi.org/10.1007/s00170-014-6028-8

[8] [8] Zhang L, Qin X, Liu P, et al. Estimation of carbon sink fluxes in the Pearl River basin (China) based on a water-rock-gas-organism interaction model[J]. Environmental Earth Sciences, 74(2), pp.945-952, 2015.

https://doi.org/10.1007/s12665-014-3788-2

[9] Negash S, Musa P, Vogel D, et al. Healthcare information technology for development: improvements in people's lives through innovations in the uses of technologies[J]. Information Technology for Development, 24(2), pp.189-197, 2018. https://doi.org/10.1080/02681102.2018.1422477

[10] [10] Armstrong D J, Riemenschneider C K, Giddens L G. The advancement and persistence of women in the information technology profession: An extension of Ahuja's gendered theory of IT career stages[J]. Information Systems Journal, (12), 2018. https://doi.org/10.1111/isj.12185 
